\title{
Corporate Governance and Risk Disclosure in Emerging Countries
}

\author{
Irina Ivashkovskaya $\bowtie$ \\ Doctor of Economics, Professor, Head of Corporate Finance Center, Head of School of Finance, \\ National Research University Higher School of Economics, Moscow, Russia, \\ iivashkovskaya@hse.ru, ORCID
}

\begin{abstract}
Musa Uba Adamu
PhD Student, School of Finance, National Research University Higher School of Economics Moscow, Russia, musubadam@gmail.com, $\underline{\text { ORCID }}$
\end{abstract}

\begin{abstract}
The study examines the influence of corporate governance attributes on the corporate risk disclosure in the emerging countries. Board size, non-executive directors, independent directors, board diversity and CEO-duality are the important board of director's composition that is considered as corporate governance variables for this study. The study focuses on South Africa and Nigeria as these countries are among major players in the African emerging market. The sample comprises 42 financial and non-financial firms listed in Nigerian Stock Exchange and Johannesburg Stock Exchange. The data was drawn from 192 annual reports for the year 2014-2018. The analytical tools employed are manual content analysis and regression. The empirical results show that operational risk disclosure outweighs environmental and strategic risk disclosure. Meanwhile, past information, non-monetary and good news are considered less relevant, however dominate future, monetary and bad news which are more valuable to diverse stakeholders. Moreover, in considering the important factors that impact on the risk confession, that board size, independent director and diversity have greater influence in driving the risk disclosure upward. Nevertheless, non-executive director and CEO-Duality are statistically insignificant in determining the movement of risk information to divulge. The persistence of contemporary corporate risk practice jampacked with irrelevant information might promote greater agency cost. The implication for the current practice might increase investors' uncertainty which in turn would raise the company cost of capital. This issue could be addressed by regulating risk disclosure in emerging countries instead of allowing corporate managers to report risk related information at their discretion. Corporate manager are also encourage to appreciate all the potential risk disclosure drivers in the African emerging countries.
\end{abstract}

Keywords: corporate risk disclosure, corporate governance, board composition, risk management, emerging countries For citation: Adamu, M. U., Ivashkovskaya, I. Corporate Governance and Risk Disclosure in Emerging Countries. Korporativnye finansy = Journal of Corporate Finance Research.2021;15(4):5-17. doi: https://doi.org/10.17323/j.jcfr.20730438.15.4.2021.5-17 


\section{Introduction}

The advocacy of risk disclosure is extensively increasing in recent years as many businesses are exposed to diverse risks. Risk disclosure is a technique of tracking, computing, managing, and revealing business prospects and challenges that may shake existing or imminent firm value to the users of corporate reporting. The advocacy was commenced for more than two decades and still very few nations in the world responded by regulating corporate risk disclosure in their jurisdictions. Nevertheless, some companies operating in non-regulating countries consider risk disclosure appropriate and are more enthusiastic to divulge their risk voluntarily. The academic community has studied several factors that affect the extent of information to be disclosed. One of the factors that were pinpointed in the literature is corporate governance. A corporate governance system is regarded as one of the crucial culprits in the financial crisis and as the power which may facilitate the economic recovery [1]. Good governance is considered as bedrock that might shape the accomplishment of organizational objectives. The code of corporate governance in many nations describes the manner in which good governance could be actualized in the organizational setting. The code that stimulates good governance and corporate disclosure would yield dynamic management that would improve profitability and firm value. However, the concept of corporate governance is highly broad and encompasses connection amongst corporate managers, board members, investors and other stakeholders [2]. Hence, several previous studies [3-16] have articulated different corporate governance mechanism and examine their impact on the quantity of risk information unveil by firm. These studies were conducted in both developed and emerging countries. Meanwhile, many prior studies [17-23] have called on the comparative studies among emerging countries and [24] emphases the study should focus on emerging countries that are situated in the African region. This study is responding to this request and would provide further insight on the risk disclosure and corporate governance literature. The study is aimed to assess the effect of board of directors' composition on corporate risk disclosure in emerging countries. The paper consists of five sections. The first is introduction, literature is reviewed in the second section, the methodology employed are described in section three, results are presented and discussed in section four, and section five concludes the study.

\section{Literature review \\ Corporate Risk Disclosure}

In recent years, business organizations are requested to divulge their risk profile in any medium such as website, annual report, interim report or any other means by which users of accounting information can access the information. The critical evaluation of these kinds of information content might influence different stakeholders' decisions. "Disclosures have been judged to be risk disclosures if the reader of annual report is informed of any business oppor- tunity or prospect, or of any hazard, harm, danger, threat or exposure, that has already impacted upon the company or may impact upon the company in the future or of the management of any such business opportunity, prospect, hazard, danger, harm, threat or exposure [25]. "The literature identifies numerous variables relative to corporate governance that influence risk disclosure behavior of corporate entities. These include corporate ownership structure, board independence and board composition". Moreover, agency theory, stakeholder theory and signaling theory are among the few theoretical frameworks usually researchers apply to explain the potential relationship between board composition (corporate governance) and risk disclosure practice by firms.

\section{Corporate Risk Disclosure and Corporate Governance}

The previous studies have sample different developed and emerging countries data and examine the influence of corporate governance variables on the quantity of risk confession. For example, a study [9] samples 424 banks among the gulf council nations and investigates their disclosure behavior. After scrutiny of 2008 annual reports of the sample companies, the findings demonstrate that Islamic financial firms divulged less risk information compared to conventional financial firms. Moreover, the greater risk confession defends on the greater quality of governance and the extent of risk confession pattern diverges across nations. In a similar study [13] explore the impact of bank governance on voluntary operational risk confession. The sample consists of 34 Islamic banks from different jurisdictions (United Arab Emirate, Dubai, Abu Dhabi, Saudi Arabia, Iran, Kuwait, Jordan, Qatar, Malaysia, and Bahrain) for the year 2008 to 2014. It is discovered that operational risk disclosure is pertinent for bank risk assessment. Moreover, auditor type, Independent directors and existence of sharia boards have positive effect on operational risk disclosure, while CEO-duality has negative effect. This indicated the CEO that chairs the board minimizes the amount of risk declaration. Meanwhile, it gives the impression that audit physiognomies presence in the bank are amongst the contributing factors on the amount of firm risk to divulge.

Moreover, the study [19] assesses the impact of banks' governance and the demographic conducts of uppermost governing gangs on the volume of risk disclosed voluntarily by Saudi Arabian banks. The analytical tool used in the measurement of quantity of risk disclosed in the listed banks annual reports is content analysis and the time span is from the year 2009 to 2013. The regression outcomes reveal that sizes of the board, gender, meetings of the audit committee and external ownership are extremely relevant on the volume of risk divulged. In a similar study, [16] evaluate the relevance of governance qualities on risk disclosure application amongst banks in Jordan. They sample 15 banks and accumulate the data from the annual report between the years 2008 to 2015 . The information is analyzed as obligatory and voluntary risk disclosure. The content analysis and OLS regression display that board size and non-exec- 
utive members, audit committee meetings and delegation of duties have a significant impact in escalating the size of voluntary risk disclosure, though management ownership is irrelevant. Nonetheless, Independent directors and the size of the audit committee are amongst the explanatory factors that explain the upward movement of mandatory risk disclosure.

In case of non-financial sector studies, scholars [26] conduct a research on corporate governance and risk in cross-listed and Canadian only companies. The sample comprises all Canadian companies included in the $\mathrm{S}$ and P/TSX Composite Index for the period 2009-2014. Results indicate that the effect of board characteristics such as size, independence and proportion of female directors remains the same in both cross-listed and not cross-listed firms. However, CEO duality and insider equity ownership impact firm risk only in cross-listed companies, while institutional shareholdings, environmental, social and governance disclosure and family control affect firm risk in Canadian only firms. Overall, the empirical results indicate that some governance mechanisms impact firm risks only in firms that cross-list, while others are well-suited for Canadian only firms. Meanwhile, researchers [10] examine the risk disclosures behavior in Spain. The study samples 35 annual reports of Spanish listed companies for the year 2009. The tools of analysis employed for the study were content analysis and regression. The empirical results demonstrate that no statistically significant relation was discovered between ownership structure, number of independent directors of the board and corporate risk disclosure.

In reference to emerging nations, the study [26] evaluates the determinants of risk disclosure behavior amongst listed companies in India. They sampled a total of 318 annual observations for the 6 years period and extracted the relevant data for the analysis. The statistical method reveals that higher size of the following: board, independent director, and gender diversity increase the volume of risk disclosure, though CEO who chairs the board contracts the extreme risk disclosure. Likewise, firms with slighter profitability, fewer liquidity and bigger in are enthusiastic to unveil superior risk information particularly old events. Furthermore, a similar study [7] investigates the role of firm governance in manipulating the degree of risk disclosure amid listed companies in South Africa. They sampled 169 firms' annual observations from the years 2002-2011. The findings reveal that significant ownership distributions in the hand of limited individuals and institutional investors' force corporate managers to release slighter risk information, nonetheless greater numbers of; non-executive, board members, and diversity of board are excited to upsurge firms' risk confession. Contrarily, the board chairman who is also the CEO is irrelevant on the amount of information to publicize.

In a similar research [12] conducted in Saudi Arabia examines the influence of board members who are from the royal family as well as the qualities of board on the volume risk to be unveiled by firms. The sample comprises 307 firms' annual observations between the years 2008 to 2011 .
The results uncovered the application of risk disclosures amongst companies are moderate. Besides, royal board members and size, board size, independence of board and frequency of board meetings have a substantial impact on the degree of risk divulged by firms.

\section{Development of Hypotheses}

\section{Board Size}

According to the agency theory, the greater board size has the potential of involving diverse expertise in the board; hence they would provide a significant role in influencing the information content of their annual reports. As noted by scholars [28], the higher board size, the greater the effectiveness in running the corporate affairs and that might improve corporate transparency with regard to risk. Likewise, the stakeholder theory reinforces that large boards tend to augment boards with different experts that can represent greater stakeholders' interest [27]. Large boards comprise mixed knowledge and diffused sentiments which toughens monitoring aptitudes and enriches company's disclosure strategy [29], although, different sentiments as well as non-integrated ideas are associated with bigger board size, thus reduced monitoring competences [27].The prior studies investigate the connection between risk disclosure and board size, and findings display diverse results. For example, the studies [30-31] have established that risk disclosure practices tend to increase provided firms have greater board size, whereas [28] find no significant effect amongst the explained and explanatory factors. Based on the aforementioned mixed findings, we proposed the following hypothesis as agency theory predicted:

H1: There is a positive association between board size and corporate risk disclosure.

\section{Non-Executive Director}

Non-executive directors are among the board composition and they are external to the company. Corporate managers could not exercise significant control or influence their behavior in the course of implementation of corporate strategic decision and risk divulging policy because they are not employees of the business. It is argued that non-executive members have to offer effective supervision that would ensure the success of a board especially by counseling, monitoring and disciplining superior managers [27]. Agency and stakeholder theories contend that the existence of non-executive members in the board composition is very crucial as their presence tends to reduce the agency cost [5]. They represent investors and other stakeholders in the board meetings especially in deliberations and executions of organizational objectives. Consequently, they are in a good position to monitor corporate managers and not to involve in any sort of conflict of interest that may arise [30]. This can be justified if they convince the board to divulge greater risk information in their annual reports for the consumption of all users [32]. The prior studies [30] confirm that volume of risk revelation increases with the proportion of non-executive members in the board. In contrast [32] does not discover any linearity amongst the 
two variables. However, consistent with the agency and stakeholder theoretical predictions the following hypothesis is considered:

H2: There is positive association between non-executive director and corporate risk disclosure

\section{Independent Directors}

The codes of governance have established a check and balance in the board due to leverage the corporate decisions and timely execution. Agency and stakeholder theories describe the association between independent members and the quantity of risk information to disclose. Agency theory suggests that the appointment of independent board members tends to shrink the agency conflict that may arise between corporate managers and investors as the level of transparency would decrease information asymmetry problems [33]. The existence of independent directors in the board might enhance corporate financial disclosures. Consistent with stakeholder theory prediction, independent board members serve as representatives to shareholders, employees, communities and other stakeholders, hence they have to monitor senior managers' activities and to ensure that the information demanded by various stakeholders are released [27].The prior studies hypothesize the possible connection between independent director and corporate risk disclosure. The studies [7] confirmed the potential linkage between the two variables, which means firms with greater independent members tend to raise their risk disclosure volume. In contrast, [34] contend that association does not exist. Despite the mixed conclusions from the literature, the hypothesis is proposed based on the agency and stakeholder theories prediction:

H3: There is positive association between independent directors and corporate risk disclosure.

\section{Diversity of the board}

Recently, scholars [35] argue that the advocacy to include a certain proportion of women in the board composition has received considerable attention". Women are anticipated to play a significant role towards actualizing the organizational objectives provided they are involved in the management teams. Nonetheless, [35] contend that agency theory does not give any explanation about the potential board effectiveness concerning gender diversity. In contrast, the other scholars [27] explained that agency theory advocates that boards with different genders can advance managerial monitoring and board independence. This assertion concurs with the signaling theory that the presence of women in the board is a good signal that might build firm reputation and increase corporate performance [27]. The women's presence in the board might create value to the firm owing to their different perspective on critical issues. There are few studies in the literature that assess the effect of gender diversity on risk disclosure. The findings of these studies [7; 27] reveal a positive association between the variables, while [26] reported non-existence of the association between diversity and risk confession. Considering the mixed result, we hypothesize based on theoretical support:
H4: There is a positive association between gender diversity and company risk disclosure

\section{CEO Duality}

The chairman of the board of directors is responsible to chair and preside over the board meetings. The code of governance proposed the division of duty between the person to chair the board and CEO. Duality exists whereby one person serves as CEO and chairman of the board. This action signals the absence of proper control in the corporate decision-making process [36]. The rationale behind segregating the two responsibilities is to promote the monitoring role and improve the quality of reporting [37]. Duality could be considered as amongst the contributing factors of quality disclosures [38] because it might influence a decision to conceal information he/she thought is detrimental to his/her position [39]. The agency theory suggests the separation between control of decision and decision management $[27 ; 36]$. However, the prior studies that investigate the potential association amongst CEO-duality and risk disclosures provide mixed results. For example, the study conducted by [39] reveals an inverse connection between CEO-duality and corporate disclosure, which indicated the volume of disclosure decreases provided the $\mathrm{CEO}$ is holding two responsibilities. In contrast, scholars [37] found a positive linearity between CEO-duality and corporate disclosure. The finding of [27] fails to establish any linkage between CEO-duality and corporate risk disclosure. Despite the above discussion and findings, the hypothesis is developed based on agency theory prediction. Thus:

H5: There is a negative association between CEO-duality and corporate risk disclosures.

\section{Methodology \\ Sample and Data}

The study samples 42 firms (see appendix 3) listed in the Nigerian Stock Exchange and Johannesburg Stock Exchange. The samples are taken from both financial and non-financial companies. In the process of selecting the financial firms, the study considers all the listed banks in both countries as a sample. However, the banks that have no adequate information are excluded from the sample. The prior studies [25] have suggested that there is no need to merge financial and non-financial firms as a sample because the financial firms are regulated by different regulations in a nation. However, the subsequent studies appear to show that there is no problem in constituting both sectors in the sample. Hence, this has motivated us to randomly select the non-financial firms operating in the manufacturing and incorporate them in the sample. Moreover, the study considers 5 years from 2014 to 2018. Therefore 210 annual reports are downloaded from the sample firms' websites. The sample was reduced to 192 due to missing data for some variable of interest. The data of all the independent variables were sourced from the Bloomberg data stream, while risk disclosure data was sourced from the 
annual reports of the sample companies. We performed manual content analysis on entire annual reports narratives including the note to account.

\section{Content Analysis}

Content analysis involves the analysis of annual report narrative sections and it is largely used in risk disclosure research. The use of this technique is consistent with previous studies $[4 ; 6 ; 25]$. In performing the content analysis, many studies coded the risk information by counting the relevant sentences, words, paragraphs, pages and percentage of pages. Consistent with prior studies [4; 6;25], we coded the risk disclosure based on frequency of relevant risk sentences reported in the annual report narratives. These types of sentences were identified based on the content of the checklist (analysis instrument) adopted from erstwhile studies $[4 ; 6 ; 25]$. The checklist was designed to make a comprehensive insight on risk disclosure analysis. Initially, the risk sentence could be coded as environmental, operational or strategic risk disclosure. Secondly, risk disclosure sentences are also analyzed as quantitative (monetary) or qualitative (non-monetary) risk information. Thirdly, the sentence could be coded as good news, neutral or bad news. Finally, we should be able to understand the risk sentences disclosed are past, non-time or future information. The checklist is presented in Table A.1 of the appendix.

\section{Measurement of Variables}

There is a need to measure our variables, so that we can run the regression and test the research hypotheses. Corporate Risk Disclosure is a dependent variable, while board size, non-executive director, independent director, diversity and CEO-duality are the independent variables of this study. Table 1 displays the proxies used in measuring the variables.

\section{Model}

$$
\begin{aligned}
& R D=\beta_{0 i t}+\beta_{1 i t}(\text { Bsize })+\beta_{2 i t}(\text { Nonex })+ \\
& +\beta_{3 i t}(\text { Independent })+\beta_{4 i t}(\text { Diversity })+ \\
& +\beta_{5 i t}(\text { Duality })+e_{i t}
\end{aligned}
$$

\begin{tabular}{|c|c|c|}
\hline Variable & Variable Description & Measurement Description \\
\hline$R D$ & Risk Disclosure & Number of risk sentences \\
\hline Bsize & Board Size & Number of people in the board \\
\hline Indirector & Independent Director & Percentage of independent director \\
\hline Nonedir & Non-executive Director & The percentage of non-executive directors \\
\hline Diversity & Women board member & The percentage of female in the board \\
\hline Duality & CEO-Duality & 1 if $\mathrm{CEO}$ is the Chairman and 0 otherwise \\
\hline
\end{tabular}

Table 1. Variable Description and measurement

\section{Results and discussion}

The descriptive statistics, diagnosis and regression result are presented and discussed in this section. Table 2 shows many random variables used. The risk disclosure outcomes are presented based on the checklist adopted in the previous study and the procedures in its measurement were discussed in detail in section three of this paper. The summary statistics of all the discrete and continuous random variables are presented with their mean, standard deviation, minimum, maximum as well as the total number of observations used. Table 2 shows the descriptive statistics of overall risk disclosure and its diverse classifications. The total risk disclosure amounted to 2089.057, 763.269, 388 and 3585 sentences for the mean, standard deviation, minimum and maximum sentences disclosed by firms respectively. Initially, the risk disclosure is classified into four different categories. In the first category, there is environmental (744.245), operational (980.365) and strategic
(366.01) risk disclosure. Based on the mean value depicted by the analysis, operational risk disclosure dominates environmental and strategic risk disclosure. In the second category, the risk disclosure sentences focused on time-horizon as either future, past or non-time information. The result indicated that non-time (920.224) is the most frequent risk sentence, whereas past information (804.385) dominates future information (366.01). This can be justified by their mean value reported in Table 2. Moreover, the third risk disclosure classified the sentences as quantitative (monetary) or qualitative (non-monetary). The mean for quantitative is 272.844 sentences, while 1817.776 sentences is peculiar to qualitative risk information. This shows that most of the disclosure is non-monetary. Meanwhile, the fourth and final risk disclosure focuses on the status of risk information as good, bad or neutral risk information. Neutral information recorded the highest mean value of 1174.641, while the mean value of good information (677.672) outweighs that of bad risk information (238.307). 
Table 2. Descriptive Statistics ${ }^{*}$

\begin{tabular}{|c|c|c|c|c|c|}
\hline Variable & Obs & Mean & Std. Dev. & Min & $\operatorname{Max}$ \\
\hline Total RD & 192 & 2089.057 & 763.269 & 388 & 3585 \\
\hline Environ RD & 192 & 744.245 & 294.012 & 126 & 1501 \\
\hline Operational RD & 192 & 980.365 & 407.545 & 142 & 1860 \\
\hline Strategic RD & 192 & 366.01 & 141.431 & 74 & 973 \\
\hline Quantitative & 192 & 272.844 & 103.837 & 60 & 710 \\
\hline Qualitative & 192 & 1817.776 & 687.56 & 272 & 3201 \\
\hline Good news & 192 & 677.672 & 281.804 & 88 & 1389 \\
\hline Bad news & 192 & 238.307 & 103.812 & 63 & 467 \\
\hline Neutral news & 192 & 1174.641 & 439.55 & 197 & 2355 \\
\hline Future info & 192 & 366.01 & 141.431 & 74 & 973 \\
\hline Past info & 192 & 804.385 & 383.284 & 99 & 1778 \\
\hline Non-time info & 192 & 920.224 & 320.796 & 169 & 1667 \\
\hline Board size & 192 & 12.526 & 3.152 & 5 & 20 \\
\hline Non-Executive & 192 & 73.896 & 12.551 & 46.15 & 100 \\
\hline Independent & 192 & 47.068 & 24.236 & 7.14 & 100 \\
\hline Diversity & 192 & 20.016 & 10.145 & 0 & 62.5 \\
\hline CEO Duality & 192 & .016 & .124 & 0 & 1 \\
\hline
\end{tabular}

* RD - Risk Disclosure; Environ - Environmental.

\section{Regression Result}

The regression result is presented in Table 3, where total risk disclosure is regressed against five explanatory factors of the board of directors' composition. The board composition includes board size, non-executive directors, independent directors, diversity and duality. The overall P-value (0.000) is significant at $1 \%$ level. In addition, the F-test is 8.176 , while R-squared is 0.180 . Based on the R-square figure, the covariates included in the model explain the variation of total risk disclosure by $18 \%$. Board size and independent directors are significant at $1 \%$, diversity is also significant at 5\% level, while non-executive directors and CEO-duality are not significant in explaining the corporate risk disclosure variation.

Table 3. Regression Result

\begin{tabular}{|c|c|c|c|c|c|c|c|}
\hline Total RD & Coef. & St. Err. & t-value & p-value & {$[95 \%$ Conf } & Interval] & Sig \\
\hline Board size & 64.028 & 16.505 & 3.88 & 0.000 & 31.466 & 96.590 & $* * *$ \\
\hline Non-Executive & -1.928 & 4.963 & -0.39 & 0.698 & -11.719 & 7.863 & \\
\hline Independent & 7.270 & 2.617 & 2.78 & 0.006 & 2.106 & 12.433 & $* * *$ \\
\hline Diversity & 13.434 & 5.172 & 2.60 & 0.010 & 3.230 & 23.638 & $* *$ \\
\hline Duality & 183.544 & 412.098 & 0.45 & 0.657 & -629.443 & 996.531 & \\
\hline Constant & 815.601 & 429.774 & 1.90 & 0.059 & -32.258 & 1663.460 & * \\
\hline
\end{tabular}

${ }^{* * *} \mathrm{p}<0.01,{ }^{* *} \mathrm{p}<0.05,{ }^{*} \mathrm{p}<0.1$. 
Table 4. Correlations

\begin{tabular}{|c|c|c|c|c|c|c|}
\hline Variables & Total RD & Board size & Non-Executive & Independent & Diversity & Duality \\
\hline Total RD & 1.000 & & & & & \\
\hline Board size & $0.286^{\star}$ & 1.000 & & & & \\
\hline Non-Executive & 0.048 & $-0.161^{\star}$ & 1.000 & & & \\
\hline Independent & $0.267^{\star}$ & 0.041 & $0.536^{\star}$ & 1.000 & & \\
\hline Diversity & $0.240^{\star}$ & 0.043 & -0.014 & $0.211^{*}$ & 1.000 & \\
\hline Duality & 0.058 & -0.034 & 0.039 & 0.134 & 0.039 & 1.000 \\
\hline
\end{tabular}

* Shows significance at the 0.05 level.

Table 5. Variance inflation factor

\begin{tabular}{|c|c|c|}
\hline & VIF & 1/VIF \\
\hline Independent & 1.567 & .638 \\
\hline Non-Executive & 1.511 & .662 \\
\hline Diversity & 1.072 & .933 \\
\hline Board size & 1.054 & .949 \\
\hline Duality & 1.023 & .978 \\
\hline Mean VIF & 1.245 & . \\
\hline
\end{tabular}

\section{Correlation}

Table 4 shows Pearson's correlations due to understanding the potential relationship among our variables. All the computation was carried out at 5\% level of significance. It is discovered that total risk disclosure is associated with non-executive, independent directors and diversity. This correlation result is similar with our regression outcome. In order to evaluate the possible multicollinearity problem, we focus on the association among explanatory factors. The results show non-executive directors $(-0.161)$ are significant and negatively associated with company size.

However, the coefficient of independent directors (0.536) is significant and positively related to non-executive directors. Diversity reveals the significant coefficient of 0.211 and positively associated with independent directors. Nonetheless, it is noticeable that all the relationship concerning the independent variables is considerably beneath the 0.80 threshold. Therefore, the model does not suffer any multicollinearity problems.

Equally, Table 5 portrays the result of variance inflation factor (VIF) for the robustness of the multicollinearity assumption. The VIF result displays all the covariates values on which 10 are believed to be a threshold for multicollinearity problem. The figures depicted were less than the threshold and this has solidified our prior finding of non-existence of multicollinearity in the model.

\section{Heteroskedasticity}

The study computed Breusch-Pagan test to ensure the homoscedasticity assumption of our error term. The result produces 1.3 and 0.2539 for chi square and p-value respectively. This is a great indication that our model is free from heteroskedasticity problems as the p-value depicted is extensively above 5\% level of significance. Furthermore, we perform the White test for the robustness of the findings. It reveals a chi square of 16.23 and a p-value of 0.5077 which is considerably more than $5 \%$ level of significance. Hence, the model complies with homoskedasticity assumption of error term (Table 5).

\section{Discussion}

The study analyses risk disclosure practice in emerging countries. The firms are constantly reporting all the risk disclosure categories, thus, environmental, operational and strategic risk disclosure. The greater frequency of operational risk disclosure above environmental and strategic is highly questionable about the quality of the disclosure. This is because, non-time and general risk management policy statement is required to classify under operational risk disclosure. This finding is consistent with the previous study [5]. The analysis instrument is designed to segregate quantitative and qualitative risk information; the result shows that lesser appearance of quantitative relative 
to quantitative risk disclosure has reduced the relevance to many stakeholders. This assertion has supported the earlier study [40] that reported similar results. Nonetheless, the future information is always more relevant to stakeholders. For example, analysts can use incorporated risk information to estimate future earnings and cash flow, however, the past information release is substantially higher than future risk information. This outcome is consistent with the prior study [25]. Despite the new dimension on how good news is considered as part of risk, nonetheless stakeholders appear more conservative by anticipating greater bad information than good one. Inappropriately, the study unveils that the good news are substantially higher than bad news. This practice might render the quality of disclosure inadequate and the result is in line with the prior findings [21].

Meanwhile, the study examines the influence of board composition on corporate risk disclosure. One of the factors to consider for the board composition is the number of people that would constitute the board, which is known as board size. Agency theory suggests that a bigger size of the board have the potential of including people with diverse knowledge in the board. Hence, they tend to influence the risk information to unveil. Based on our findings, board size is statistically significant at $1 \%$ level and influences the greater confession of risk information. The result is in line with erstwhile studies $[21 ; 31]$ and backs the assertion that as board size increases, the effectiveness and corporate risk transparency is also increased. Therefore, consistent with agency theory prediction our hypothesis I is accepted.

Non-executive director is among the board composition that would improve the firm corporate governance. Including non-executive in the board composition could reduce the agency cost [36] as they are in a good position to monitor corporate managers in the event of conflict of interest [30]. The potential linkage we suggested between non-executive director and risk disclosure is not evidenced as our coefficient turnout to be insignificant. This finding is consistent with the previous study [19], however inconsistent with the study [30]. Hence, the results do not support the hypothesis 2 which postulated the positive association amongst the two variables.

Independent director is also another board of directors' composition. The code of corporate governance suggests the appointment of independent directors due to leverage the decision making process and maintains appropriate check and balance in the board. This process has strong implications by sliding agency conflict that might arise and also enhance transparency. Considering the potential association between corporate risk disclosure and independent directors, our findings have confirmed this proposition as the coefficient is significant at $1 \%$ confidence level. The board composition with greater independent members tends to report higher risk information. This supports the previous studies $[5 ; 41]$. Therefore, hypothesis 3 is accepted.

Diversity is one amongst the contemporary board composition. In recent years there is great activism to involve females in the board composition. Nevertheless, the relevance of diversity is ignored in the agency theory, howev- er, the way females perceive things in the decision process might create further firm value. Diversity being one of the board compositions, the potential association is also studied. The findings suggest a positive association between diversity and corporate risk disclosure. This can be justified by a positive coefficient that is statistically significant at $5 \%$ level. The result supported the previous study [7] and also our hypothesis which postulated the positive relationship between the two variables. Hence, hypothesis 4 is accepted.

Duality is one of the board compositions where the CEO is the chairman of the board and saddles with responsibility to chair and preside over the board meetings. Ideally, the division of duty is more appropriate as suggested by corporate governance code. The rationale behind segregating the two responsibilities is to promote the monitoring role and improve the quality of reporting [37]. The possible influence of duality in relation to the risk disclosure was examined and the coefficient is not statistically significant which provides an absent of relationship between the two variables. This finding is inconsistent with the prior empirical studies [22]. Decisively, hypothesis 5 that suggests negative association amongst the variables is rejected as there is no sufficient evidence to establish it.

\section{Conclusion}

The paper evaluates the impact of board composition on corporate risk disclosure in the emerging countries. It is evidenced by greater board size; independent director and board diversity have great influence in moving risk disclosure upward. Nevertheless, non-executive and CEO-Duality have no effect on the magnitude of risk information disclosed. In addition, in terms of risk disclosure and nature, operational risk disclosures dominate environmental and strategic risk disclosures. Most of the information included in the operational risk disclosure is neutral, qualitative and non-time. The higher presence of general statement and risk definitions has reduced the relevance of risk disclosure to users. Quantitative, future and bad news are the most valuable risk information that could help stakeholders' decisions, however qualitative, past and good news are the most recurrent risks unveiled by firms. This development has shown a strong partiality in the selection of risk revelation. Likewise, the risk confession is greater for the financial sector and the overall disclosure is higher for South African firms. Despite the less pertinent risk information uncovered by firms, nonetheless, the overall companies' disclosure is increasing annually. Meanwhile, the absence of a comprehensive risk disclosure framework from the regulators has caused lack of uniformity on style corporate managers divulging risk information voluntarily. The findings posit that listed firms from emerging African countries divulge risk information in their annual report; however there is need to improve risk information that is more pertinent to users of accounting information. The company that constitutes their board with many people, independent directors and diversity tend to increase their risk revelation. These findings have implications to several stakeholders such as investors, regulators and African emerging markets. 
The major limitation identified in this study was risk disclosure coding procedure. There is an element of subjectivity in all risk disclosure studies especially the manner in which the information is collected in the annual report narratives. However, in order to reduce the potential bias, we employ a manual approach which is the most hard and time consuming to execute by counting the relevant risk sentences based on the decision rule adopted from prior studies. Before coding any sentence, a reference has to be made to ensure that risk sentence is coded and recorded accordingly. This approach would improve the potential subjectivity earlier anticipated. The future studies could explore the potential influence or otherwise of board meetings and attendance on corporate risk disclosure. Secondly, the literature has highlighted the extent of risk associated with intangible asset and intellectual capital; therefore future studies could investigate if the firms with greater intangible asset or intellectual capital divulge greater risk information in both advanced and emerging countries.

\section{References}

1. Ivashkovskaya I., Zinkevich N. The relationship between corporate governance and company performance in concentrated ownership systems: The case of Germany. Korporativnye finansy = Journal of Corporate Finance Research. 2009;3(4):34-56. https://doi.org/10.17323/j.jcfr.20730438.3.4.2009.34-56

2. Bhasin M.L. Voluntary corporate governance disclosures: An exploratory study. International Journal of Contemporary Business Studies. 2012;3(9):6-26. https://doi.org/10.1016/j. intacc.2004.06.006

3. Beretta S., Bozzolan S. A framework for the analysis of firm risk communication. The International Journal of Accounting. 2004;39(3):265-288. https://doi. org/10.1016/j.intacc.2004.06.006

4. Rajab B., Handley-Schachler M. Corporate risk disclosure by UK firms: Trends and determinants. World Review of Entrepreneurship Management and Sustainable Development.2009;5(3):224-243. https:// doi.org/10.1504/WREMSD.2009.026801

5. Oliveira J., Lima Rodrigues L., Craig R. Voluntary risk reporting to enhance institutional and organizational legitimacy: Evidence from Portuguese banks. Journal of Financial Regulation and Compliance. 2011;19(3):271-289. https://doi. org/10.1108/13581981111147892

6. Adamu M.U. Risk disclosure: A study of risk disclosure in the annual reports of listed companies in Nigeria. Research Journal of Finance and Accounting. 2013;4(16):140-148. URL: https://www. iiste.org/Journals/index.php/RJFA/article/view/8294 (accessed on 30.11.2020).

7. Ntim C.G., Lindop S., Thomas D.A. Corporate governance and risk reporting in South Africa: A study of corporate risk disclosures in the pre- and post-2007/2008 global financial crisis period. International Review of Financial Analysis. 2013;30:363-383. https://doi.org/10.1016/j. irfa.2013.07.001

8. Ali M.M., Taylor D. Corporate risk disclosure in Malaysia: the influence of predispositions of chief executive officers and chairs of audit committee. Research Journal of Finance and Accounting. 2014;5(2):92-106. https://doi.org/10.5176/2251-1997

9. Abdallah A.A.-N., Hassan M.K., McClelland P.L. Islamic financial institutions, corporate governance and corporate risk disclosure in Gulf Cooperation Council countries. Journal of Multinational Financial Management. 2015;31:63-82. https://doi. org/10.1016/j.mulfin.2015.02.003

10. Madrigal M.H., Guzmán B.A., Guzmán C.A. Determinants of corporate risk disclosure in large Spanish companies: A snapshot. Contaduría y Administración. 2015;60(4):757-775. https://doi. org/10.1016/j.cya.2015.05.014

11. Al-Hadi A., Hasan M.M., Habib A. Risk committee, firm life cycle, and market risk disclosures. Corporate Governance: An International Review. 2016;24(2):145170. https://doi.org/10.1111/corg.12115

12. Habtoor O.S., Ahmad N. The influence of royal board of directors and other board characteristics on corporate risk disclosure practices. Corporate Ownership \& Control. 2017;14(2):326-337. https:// doi.org/10.22495/cocv14i2c2p6

13. Neifar S., Jarboui A. Corporate governance and operational risk voluntary Ddisclosure: Evidence from Islamic banks. Research in International Business and Finance. 2018;46:43-54. https://doi.org/10.1016/j. ribaf.2017.09.006

14. Mazaya N., Fuad F. Business strategy, corporate governance, firm characteristics, and risk disclosure in the Indonesian Stock Exchange. Jurnal Keuangan dan Perbankan = Finance and Banking Journal. 2018;22(3):381-394. https://doi.org/10.26905/jkdp. v22i3.2167

15. Dobler M., Luckner M. Risk disclosures, governance and ownership: Evidence from German non-listed firms. Corporate Ownership \& Control. 2018;15(4):4657. https://doi.org/10.22495/cocv15i4art4

16. Alkurdi A., Hussainey K., Tahat Y., Aladwan M. The impact of corporate governance on risk disclosure: Jordanian evidence. Academy of Accounting and Financial Studies Journal. 2019;23(1):1-16. URL: https://www.abacademies.org/articles/the-impact-ofcorporate-governance-on-risk-disclosure-jordanianevidence-7886.html

17. Vandemaele S., Vergauwen P., Michiels A. Management risk reporting practices and their determinants: A study of Belgian listed firms. 2009. URL: https://www.researchgate.net/ publication/277755521 (accessed on 20.11.2020). 
18. Semper D.C., Beltrán J.M.T. Risk disclosure and cost of equity: The Spanish case. Contaduría $y$ Administración. 2014;59(4):105-135. https://doi. org/10.1016/S0186-1042(14)70157-3

19. Al-Maghzom A., Hussainey K., Aly D. Corporate governance and risk disclosure: Evidence from Saudi Arabia. Corporate Ownership and Control. 2016;13(2):145-166. https://doi.org/10.22495/ cocv13i2p14

20. Al-Shammari B. Kuwait corporate characteristics and level of risk disclosure: A content analysis approach. Journal of Contemporary Issues in Business Research. 2014;3(3):128-153. URL: https://citeseerx.ist.psu.edu/ viewdoc/download?doi=10.1.1.679.8822\&rep=rep1\& type $=$ pdf (accessed on 20.11.2020).

21. Serrasqueiro R.M., Mineiro T.S. Corporate risk reporting: Analysis of risk disclosures in the interim reports of public Portuguese nonfinancial companies. Contaduría y Administración. 2018;63(2):991-1013. https://doi.org/10.22201/ fca.24488410e.2018.1615

22. Elshandidy T., Neri L., Guo Y. Determinants and impacts of risk disclosure quality: Evidence from China. Journal of Applied Accounting Research. 2018;19(4):518-536. https://doi.org/10.1108/JAAR07-2016-0066

23. Salem I.H., Ayadi S.D., Hussainey K. Corporate governance and risk disclosure quality: Tunisian evidence. Journal of Accounting in Emerging Economics. 2019;9(4):567-602. https://doi. org/10.1108/JAEE-01-2019-0005

24. Wachira M. Corporate governance and risk disclosure: An empirical study of listed companies in Kenya. African Journal of Business Management. 2019;13(17):571-578. https://doi.org/10.5897/ AJBM2019.8867

25. Linsley P.M., Shrives P.J. Risk reporting: A study of risk disclosures in the annual reports of UK companies. The British Accounting Review. 2006;38(4):387-404. https://doi.org/10.1016/j.bar.2006.05.002

26. Chakraborty A., Gao L., Sheikh S. Corporate governance and risk in cross-listed and Canadian only companies. Management Decision.

2019;57(10):2740-2757. https://doi.org/10.1108/MD10-2017-1052

27. Saggar R., Singh B. Corporate governance and risk reporting: Indian evidence. Managerial Auditing Journal. 2017;32(4-5):378-405. https://doi. org/10.1108/MAJ-03-2016-1341

28. Elzahar H., Hussainey K. Determinants of narrative risk disclosures in UK interim reports. Journal of Risk Finance. 2012;13(2):133-147. https://doi. org/10.1108/15265941211203189

29. Adams R.B., Almeida H., Ferreira D. Powerful CEOs and their impact on corporate performance. The Review of Financial Studies. 2005;18(4):1403-1432. https://doi.org/10.1093/rfs/hhi030
30. Abraham S., Cox P. Analyzing the determinants of narrative risk information in UK FTSE 100 annual reports. The British Accounting Review. 2007;39(3):227-248. https://doi.org/10.1016/j. bar.2007.06.002

31. Lajili K. Corporate risk disclosure and corporate governance. Journal of Risk and Financial Management. 2009;2(1):94-117. https://doi. org/10.3390/jrfm2010094

32. Barako D.G., Hancock P., Izan H.Y. Factors influencing voluntary corporate disclosure by Kenyan companies. Corporate Governance: An International Review. 2006;14(2):107-125. https://doi.org/10.1111/ j.1467-8683.2006.00491.x

33. Fama E.F. Agency problems and the theory of the firm. Journal of Political Economy. 1980;88(2):288307. URL: https://josephmahoney.web.illinois.edu/ BA549_Fall\%202010/Session\%205/Fama\%20(1980). pdf

34. Elshandidy T., Neri L. Corporate governance, risk disclosure practices, and market liquidity: Comparative evidence from the UK and Italy. Corporate Governance: An International Review. 2015;23(4):331-356. https://doi.org/10.1111/ corg. 12095

35. Ellwood S.M., Garcia-Lacalle J. The influence of presence and position of women on the boards of directors: The case of NHS foundation trusts. Journal of Business Ethics.2015;130(1):69-84. https://doi. org/10.1007/s10551-014-2206-8

36. Fama E.F., Jensen M.C. Separation of ownership and control. The Journal of Law and Economics. 1983;26(2):301-325. https://doi.org/10.1086/467037

37. Haniffa R., Cooke T.E. Culture, corporate governance and disclosure in Malaysian corporations. Abacus: A Journal of Accounting Finance and Business Studies. 2002;38(3):317-349. https://doi.org/10.1111/14676281.00112

38. Forker J.J. Corporate governance and disclosure quality. Accounting and Business Research. 1992;22(86):111-124. https://doi.org/10.1080/000147 88.1992.9729426

39. Apostolou K.A., Nanopoulos A.N. Voluntary accounting disclosure and corporate governance: Evidence from Greek listed firms. International Journal of Accounting and Finance. 2009;1(4):395-414. https:// doi.org/10.1504/IJAF.2009.029146

40. Linsley P.M., Shrives P.J., Crumpton I. Risk disclosure: An exploratory study of UK and Canadian banks. Journal of Banking Regulation. 2006;7(34):268-282. https://doi.org/10.1057/palgrave. jbr.2350032

41. Abd Elghafgar E.S., Abotalib A.M., Khalil M.A.A. Determining factors that affect risk disclosure level in Egyptian banks. Banks and Bank Systems. 2019;14(1):159-171. https://doi.org/10.21511/ bbs.14(1).2019.14 


\section{APPENDIX 1}

Table A1. Risk Disclosure Categories Checklist

\section{Risk Category} Disclosure Items

Environmental risk arises from factors essentially beyond the organization's control and comprises disclosure relating to:

Economic risk (e.g., interest rate, currency risk, price and commodity, inflation, taxation, credit risk); Political risk; Social risk: such as kidnaping or murder of key staff,

1 Environmental Risk firm's asset vandalized by protesting citizens, pilferages, xenophobia, book haram, tribal and inter-religious crisis, fake currency, bad debts; Regulation and Legislation; Industry sources (e.g., competition, potential entrants, suppliers, substitutes, strategic partners, customers (e.g., changes in demand, changes in clients requirements and customers preferences); Climate and catastrophic.

Operational risk is the probability of losses arising from the essential operation side of the firm. Operational risk covers such issues as:

2 Operational Risk Internal control and risk management policies; Infrastructure risk; Liquidity and cash flow; Project failure; Product failure; Operational disruption; Operational problem; Employment practices and workplace safety ( $\mathrm{H}$ and $\mathrm{S}$ ); Environment risk (risks arising from the impact of companies' operations on the natural environment); Compliance and reputation; Legal risk.

Strategic risks arise from operating in a particular industry and are associated with the company's future business plans and strategies. Strategic risks encompass:

3 Strategic Risk Research and Development; Product market; Intellectual property right; Acquisitions, alliances, joint ventures; Management of growth; Derivatives; Investment; Technology. 


\section{APPENDIX 2}

Table A2. Decision rules for risk disclosures

\section{Decision Rules For Risk Disclosure}

1. To identify risk disclosures a broad definition of risk is to be adopted as explained below.

2. Sentences are to be coded as risk disclosures if the reader is informed of any opportunity or prospect, or of any hazard, danger, harm, threat or exposure, that has already impacted upon the company or may impact upon the company in the future or of the management of any such opportunity, prospect, hazard, harm, threat or exposure.

3. The risk definition just stated shall be interpreted such that 'good' and 'bad' 'risks' and 'uncertainties' will be deemed to be contained within the definition.

4. Although the definition of risk is broad, disclosures must be specifically stated; they cannot be implied

5. The risk disclosures shall be classified according to the grid in Table 1, and by reference to the Appendix A risk categories

6. Sentences of general policy concerning internal control and risk management systems, corporate governance, employee health and safety shall be classified as 'non-monetary/neutral/non-time specific statements of risk management policy

7. Sentences of general policy concerning financial risk management shall be classified 'non-monetary/ neutral/nontime specific statements of risk management policy.

8. Monetary risk disclosures are those risk disclosures that either disclose directly the financial impact of a risk or disclose sufficient information to enable the reader to calculate the financial impact of a risk.

9. If a sentence has more than one possible classification, the information will be classified into the category that is most emphasized within the sentence.

10. Tables (quantitative and qualitative) that provide risk information should be interpreted as one line equals one sentence and classified accordingly.

11. Any disclosure that is repeated shall be recorded as a risk disclosure sentence each time it is discussed.

12. If a disclosure is too vague in its reference to risk, then it shall not be recorded as a risk disclosure. 


\section{Appendix 3.}

\section{Sample Firms}

\begin{tabular}{|c|c|c|}
\hline Stock Exchange Market & Sector & Sample \\
\hline Nigeria Stock Exchange & Banking & 8 \\
\hline Nigeria & Industrial & 3 \\
\hline Nigeria & Consumer goods & 6 \\
\hline Nigeria & Oil and Gas & 2 \\
\hline Nigeria & Consumer Service & 1 \\
\hline Johannesburg Stock Exchange & Bank & 4 \\
\hline Johannesburg Stock Exchange & Financial Service 59 & 2 \\
\hline Johannesburg Stock Exchange & Life Assurance & 2 \\
\hline Johannesburg Stock Exchange & Mobile Telecommunications & 2 \\
\hline Johannesburg Stock Exchange & Construction \& Materials & 1 \\
\hline Johannesburg Stock Exchange & Mining & 2 \\
\hline Johannesburg Stock Exchange & Industrial Metals \& Mining & 1 \\
\hline Johannesburg Stock Exchange & General Industrials & 2 \\
\hline Johannesburg Stock Exchange & Oil \& Gas Producers & 1 \\
\hline Johannesburg Stock Exchange & Food \& Drug Retailers & 1 \\
\hline Johannesburg Stock Exchange & Tobacco & 1 \\
\hline Johannesburg Stock Exchange & Media & 1 \\
\hline Johannesburg Stock Exchange & Personal Goods & 1 \\
\hline Johannesburg Stock Exchange & General Industrials & 1 \\
\hline
\end{tabular}

Source: URL: https://www.african-markets.com/en/stock-markets/ngse/listed-companies.

Contribution of the authors: the authors contributed equally to this article.

The authors declare no conflicts of interests.

The article was submitted 06.10.2021; approved after reviewing 08.10.2021; accepted for publication 14.10.2021. 